
\title{
3 Research Square \\ Plant Species Over-Occupancy Indicates River Valleys Are Natural Corridors for Migration
}

\section{Anežka Holeštová ( $\nabla$ holestova@fzp.czu.cz)}

Czech University of Life Sciences Prague: Ceska Zemedelska Univerzita v Praze https://orcid.org/0000-0001-6115-4298

Jan Douda

Czech University of Life Sciences Prague: Ceska Zemedelska Univerzita v Praze

\section{Research Article}

Keywords: Ancient forests, Colonisation rate, Dispersal limitation, River phenomenon, River valley, Species richness

Posted Date: June 4th, 2021

DOI: https://doi.org/10.21203/rs.3.rs-542358/v1

License: (c) (i) This work is licensed under a Creative Commons Attribution 4.0 International License. Read Full License

Version of Record: A version of this preprint was published at Plant Ecology on October 9th, 2021. See the published version at https://doi.org/10.1007/s11258-021-01191-9. 


\section{Abstract}

River valleys are considered natural corridors for migration of plant species, however, there is a lack of studies confirming higher colonisation rates of plant species in these areas. We compare plant speciesrichness between ancient and recent forests, and those located in a river valley with those located in the surrounding landscape. We hypothesise that, close to a river, higher plant species-richness will be associated with recent forests thus indicating a higher colonisation rate. The study area includes part of the Elbe River Valley and its surrounding landscape in the Czech Republic. We sampled an equal number of recent and ancient forests but lying at different distances from the river. We used generalised linear models to test the effect of distance from the river in dependence upon forest continuity (recent/ancient forest) on two plant species-richness categories, i.e. richness of forest species and overall species richness. In the surrounding landscape, higher richness of forest species was associated with ancient forests, whereas overall species richness was comparable. In the river valley, richness of forest species as well as overall species richness was higher in the recent forests. Recent forests in the river valley were more saturated by plant species than those in the surrounding landscape, indicating that in the river valley the colonisation rate of plant species is higher. These results confirm the importance of river valleys as natural corridors for migration of plant species.

\section{Introduction}

It is well known that the plant species diversity is markedly different in a river valley compared to in the surrounding flat landscape (Blažková 1964; Naiman et al. 1993; Renöfält et al. 2005; Zelený and Chytrý 2007; Nobis et al. 2016). Hence, river valleys are frequently identified as regional hotspots of biodiversity and are also regarded as natural corridors for plant species migration (Jeník and Slavíková 1964; Tockner and Ward 1999; Ward et al. 2001; Saarela et al. 2017). However, we lack studies which estimate whether the colonisation rate of plant species is actually higher in a river valley, than in the surrounding landscape.

The linear connectivity of a river valley allows plant species to migrate in both downstream and upstream directions and also along interconnecting gullies and so colonise suitable habitats (Gallé et al. 1995; Ward et al. 2002; Czochański and Wiśniewski 2018). Here, the colonisation rate decreases as the target habitats become more distant from the riverbank which serves as a source of diaspores. Correspondingly, the decrease in habitat connectivity outside of a river valley has a negative effect on colonisation rate (Yao et al. 1999; Renöfält et al. 2005; Vellend 2016; Nobis et al. 2016; Nobis et al. 2017). For example, the oak-hornbeam forests of central Europe offer highly connected habitats along the slopes of river valleys, whereas outside of these a patchy agricultural landscape dominates (Chytrý 2013). Therefore, outside of a river valley, compared to colonisation, both the distance from the riverbank and also habitat fragmentation increase the importance of local community processes including competition and ecological drift. The ecological drift and competition at any particular site increase the chances of species extinction. Thus, the balance between the rate of colonisation and that of extinction determines the composition and species richness of a local plant community (Vellend 2016). 
Whether or not a plant species reaches a remote habitat, depends on its colonisation ability. For example, both anemochorous and zoochorous species produce many seeds which can move over large distances, however, colonisation success is also affected by the seedling establishment conditions. Since prehistory in Europe, forest cover has gradually decreased accompanied by a corresponding increase in cropland cover (Bellemare et al. 2002; Pongratz et al. 2008). Since the intensification of farming practices in the 20th century, many croplands formerly established on forest soils have been abandoned and the land has returned to forest (Mather et al. 1999). Therefore, two types of forests can be found in European landscapes that differ in respect to their times of origin. Ancient forests are associated with land has enjoyed continuous forest land use, while recent forests are associated with land that has suffered temporarily use as pasture, or for arable cropping or for horticulture (Koerner et al. 1997; Webb 1998). River valleys have been less exposed to these human-induced changes due to their rugged topography, although evidence of some traditional farming practices can still be seen in the more accessible locations (Douda 2010). A good number of studies have shown that higher plant species richness is associated with ancient forests due to their long and continuous history (Peterken and Game 1984; Dzwonko and Gawronsky 1992; Hermy et al. 1999; Wulf 2003; Sciama et al. 2009; Matuszkiewicz et al. 2013). Furthermore, particular groups of species are related to ancient forests, namely ancient forest species that have been found to serve well as indicators of forest communities and these are characterised by high diversity (Hermy et al. 1999; Douda 2010; Stefańska-Krzaczek et al. 2016). The recent forests are dependent on diaspore input from ancient forests, i.e. colonisation success increases in proximity to an ancient forest, and recent forests continuous with ancient forests may also be colonised by herbaceous species (Dzwonko 1993; Wulf and Heinken 2008; Orczewska 2010; Orczewska and Fernes 2011).

Disentangling the importance of the processes that drive the plant species richness of riverine communities, requires information on plant species colonisation. In previous studies, a number of authors have described the patterns of plant species richness along a gradient starting in a river valley and continuing into the surrounding landscape (i.e., a riverine gradient, Blažková 1964; Ložek 1974; Chytrý and Tichý 1998; Renöfält et al. 2005; Zelený and Chytrý 2007; Nobis et al. 2016). Here we seek to provide an additional step in understanding how well plant species richness copes with the riverine phenomenon by recording the species saturation of forest communities along a riverine gradient. We compare plant species richness between ancient and recent forests where ancient forests are considered to be areas of continuously forested land, at least since the second half of the 19th century, whereas recent forests are those that have originated after that time. This method allows us to estimate how successfully recent forests are colonised at different distances from the river and to associate the riverine gradient with the importance of the colonisation processes. The ancient forests provide us information on plant species richness determined by the long-term balance between colonisation, extinction and environmental conditions. Recent forests inform us as to whether the plant species richness here has reached a value close to the natural state in an ancient forest due to the rapid spread of plant species or whether the dispersal of plant species is more limited, so that the recent forests are less saturated than the ancient forests. Use of Ellenberg indicator values (EIVs) helps us to understand patterns of plant species composition in respect to changing environmental conditions along the riverine gradient. 
Assessing the distribution of plant dispersal vectors in forests located in, and outside, the river valley further contributes to a better explanation of the colonisation processes. Specifically, we ask: How do plant species-richness and the prevailing dispersal mode differ between ancient and recent forests, with respect to the distance from a river? We would expect that plant species-richness will be more similar between ancient and recent forests if these are located close to a river, due to their connectivity with the river corridor that will enhance the colonisation rate of plant species. Due to higher connectivity between recent and ancient forests, we also expect higher proportions of species with limited dispersal, such as myrmecochorous forest species, in recent forests in a river valley. Conversely, we would expect that a recent forest far from a river, will be less saturated with plant species, compared with an ancient forest, due to more limited dispersal. Therefore, if present, forest species will be represented dominantly by anemochorous species.

\section{Methods}

\section{Study area}

The study was conducted about halfway along the course of Elbe River located in the northern part of the Czech Republic ( $\left.14^{\circ} 09^{\prime} 25^{\prime \prime}-14^{\circ} 09^{\prime} 47^{\prime \prime} \mathrm{E}, 50^{\circ} 41^{\prime} 53^{\prime \prime}-50^{\circ} 42^{\prime} 29^{\prime \prime} \mathrm{N}\right)$. The Elbe River Valley is considered one of the most important natural corridors for species migration in Europe. The study area covers ca. $10 \mathrm{~km}^{2}$ and includes the western slope of the river valley and its surrounding landscape (Fig. 1). The altitude ranges from $153 \mathrm{~m}$ to $340 \mathrm{~m}$ above mean sea level. The climate is subcontinental with annual mean temperature ca. $9^{\circ} \mathrm{C}$. The mean annual precipitation ranges from 450 to $800 \mathrm{~mm}$ (Bína and Demek 2012). The whole area is a part of a protected landscape České středohoří (IUCN category V) and comprises many primary but also secondary ecosystems including ancient and recent forests. It therefore represents a suitable model system for studying patterns of plant species richness in forests along a riverine gradient.

\section{Sampling}

To select the vegetation plots for random-stratified sampling, the study area was overlaid with a square grid with cells of $200 \times 200 \mathrm{~m}$. For each cell, forest continuity (ancient/recent forest) was determined based on a comparison of current with historical maps, specifically the third military mapping of AustriaHungary from $1877-1880$ on a scale of $1: 75000$ (http://oldmaps.geolab.cz/). The grid cells were grouped into five 600-m-wide strips, corresponding to their different distances from the river. In each strip, the cells of ancient/recent forest were numbered. Four of these cells were then selected at random and vegetation plots were established at their centres. In cases where ancient/recent forest was absent in a cell centre, the vegetation plot was established in the nearest location in which the forest occurred (Fig. 1). In this way, eight vegetation plots (four ancient forest plots and four recent forest plots) were established in each $600 \mathrm{~m}$ strip. Data was collected in July 2016. A list of vascular plants (shrubs and 
trees) with species cover was recorded for each plot using the nine-step ordinal Braun-Blanquet scale (Braun-Blanquet 1964; Podani 1984). The standard plot size used for sampling was $400 \mathrm{~m}^{2}$.

\section{Delimitation of variables}

Forest species were selected from the overall dataset based on a study by Chytrý and Tichý (2003), which categorised the affinity of plant species to forest habitats. The number of species belonging to the forest species category (richness of forest species) and the number of all species (overall species richness) were calculated for each vegetation plot. The full list of species recorded, with forest species highlighted, is provided in Supplement Table 1. The nomenclature follows Kaplan et al. (2019).

Table 1

The effects of forest continuity, distance from the river and their interaction on plant species richness, dispersal and Ellenberg indicator values is shown by generalised linear models.

\begin{tabular}{|c|c|c|c|}
\hline & $\begin{array}{l}\text { Forest continuity } \\
\text { (Forest) }\end{array}$ & Distance from river (Dist) & ForestDist \\
\hline \multicolumn{4}{|l|}{ Plant species richness } \\
\hline Richness of forest species & $0.043^{\star}$ & $<0.001 * \star \star$ & $0.0342^{\star}$ \\
\hline Overall species richness & $0.00158 * *$ & $<0.001 * \star \star$ & 0.02487 * \\
\hline \multicolumn{4}{|l|}{ Dispersal mode } \\
\hline Autochory & 0.0279 * & 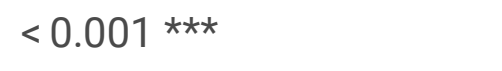 & ns \\
\hline Anemochory & ns & 0.0291 * & ns \\
\hline Endozoochory & 0.0244 * & 0.0380 * & ns \\
\hline Epizoochory & ns & 0.0365 * & ns \\
\hline Myrmecochory & 0.0537 & $<0.001 * \star \star$ & ns \\
\hline \multicolumn{4}{|l|}{ Ellenberg indicator values } \\
\hline Nutrients & ns & 0.0256 * & ns \\
\hline Soil reaction & ns & ns & ns \\
\hline Moisture & ns & ns & ns \\
\hline Light & ns & ns & ns \\
\hline$\star \star \star * P<0.001, * \star=P<0.01$ & $=\mathrm{P}<0.05, \mathrm{~ns}=\mathrm{n}$ & -significant & \\
\hline
\end{tabular}

The shortest distance from each plot centre to the river was calculated. This distance ranged from a minimum of $56 \mathrm{~m}$ (for a plot lying adjacent to the river) to a maximum of $2840 \mathrm{~m}$ (for the most distant plot). 
For each species, dispersal mode was assigned according to the LEDA database (Kleyer et al. 2008) and the number of species within each mode (autochory, anemochory, endozoochory, epizoochory, myrmecochory) was then calculated for each vegetation plot. For each vegetation plot, the mean EIVs for nutrients, soil reaction, moisture and light were also calculated and weighted on species cover (Ellenberg et al. 1992).

It is generally well known that the plant species-richness of a recent forest is affected by proximity to ancient forest. Specifically, the closer a recent forest is to an ancient forest, the higher is the number of plant species present (Dzwonko 1993). Therefore, it is likely that the plant species-richness of a recent forest will be affected not only by distance from a river but also by distance from the nearest ancient forest. To control this effect, the distance from each recent forest plot to the nearest ancient forest plot was calculated (distances ranged from a minimum of $179 \mathrm{~m}$ to a maximum of $968 \mathrm{~m}$ ) and its effect on plant species-richness in the recent forest was also assessed.

\section{Statistical analyses}

To estimate how successfully recent forests are colonised at different distances from the river, the effect of distance from the river in dependence upon forest continuity (recent/ancient forest) on richness of forest species/overall species richness was tested using generalised linear models with Poisson response distributions.

Several additional analyses were carried out to explain the observed patterns: First, to relate the colonisation rate to the dispersal traits of recorded species, the effect of distance from the river in dependence upon forest continuity and on richness of autochorous, anemochorous, endozoochorous, epizoochorous and myrmecochorous species was tested using generalised linear models with Poisson response distributions.

Second, to assess the change in environmental conditions along the riverine gradient, the effect of distance from the river in dependence upon forest continuity on distributions of the EIVs for nutrients, soil reaction, moisture and light were tested using generalised liner models. In this case, the Gaussian response distribution was used, as the original EIVs were converted on weighted means.

Third, to assess whether the proximity to an ancient forest contributes to higher plant species-richness of recent forests, the effect of the interaction between the distance from the river and the distance from an ancient forest (and the separate effects) on richness of forest species/overall species richness in recent forests were tested using generalised linear models with Poisson response distributions. Similar analyses were also used to test the effects of the putative interactions of the richness of autochorous, anemochorous, endozoochorous, epizoochorous and myrmecochorous species in recent forests.

Fourth, detrended correspondence analysis (DCA) was used to assess the overall pattern of variation in species composition. The analyses were carried out using the decorana function in the R package Vegan (Oksanen et al. 2020). To interpret the DCA results in terms of environmental gradients, the significant Ellenberg indicator values were then plotted onto a DCA ordination diagram as supplementary variables 
using the envfit function from the same R package. Envfit provides a vector for each variable that maximises correlation between that variable and the projections of ordination points onto that vector. Significance was assessed using permutation of variables. All statistical analyses were carried out in the statistical program R (R Development Core Team 2019).

\section{Results}

In general, significant positive correlations were found between distance from the river and each speciesrichness category (i.e., overall and forest-species richness). Higher numbers of species were associated with plots located far from the river (outside the river valley), whereas lower number of species persisted on plots located closer to the river (in the river valley) (Table 1; Fig. 2). Both species-richness categories differed significantly for ancient and recent forests (i.e., forest continuity) (Table 1; Fig. 2).

Higher richness of forest species was associated with recent forests in the river valley, whereas outside of the river valley higher richness of forest species was associated with ancient forests. Specifically, the number of species in recent forests located closer to the river $(0.056-1.06 \mathrm{~km})$ was 1.6-times higher compared with ancient forests at the same distances. On the other hand, the number of species in recent forests located far from the river (1.07-2.84 km) was 1.14-times lower (Fig. 2a).

In contrast, higher overall species-richness was associated with recent forests in the river valley as well as those outside the river valley, however, the difference in the numbers of species between ancient and recent forest decreased gradually as distances increased. Specifically, the numbers of species in recent forests located close to the river (0.056-1.06 km) were 1.8-times higher compared with in ancient forests at the same distance, whereas the numbers of species in recent forests located far from the river were comparable with the numbers of species in ancient forests (Fig. 2b).

A significant positive correlation was found between distance from the river and the dispersal mode. However, we recorded significantly higher numbers of autochorous, endozoochorous and myrmecochorous species associated with recent forests along the entire length of the riverine gradient. In cases of endozoochory and myrmecochory, the numbers of species were higher in plots located close to the river (Table 1; Fig. 3 ).

Significant positive correlations with distance from the river were found only for the EIVs for nutrients. However, these EIVs did not differ significantly between ancient and recent forests (Table 1; Fig. 4). This result was also supported by the DCA ordination, indicating that the riverine gradient is correlated with the EIV for nutrients, which explains the most important part of the variability in the species-composition data (Table 2; Fig. 5). 
Table 2

The significances of the environmental variables are shown by the envfit function from the R package Vegan.

\begin{tabular}{|c|c|c|c|c|}
\hline & DCA1 & DCA2 & $\mathrm{r} 2$ & $\mathbf{P}$ \\
\hline Distance from river (Dist) & -0.0942 & -0.9956 & 0.217 & 0.015 * \\
\hline Nutrients & -0.586 & -0.8103 & 0.6371 & $<0.001 * * *$ \\
\hline Moisture & -0.0611 & -0.9981 & 0.4346 & $<0.001 * \star * x$ \\
\hline Soil Reaction & -0.984 & -0.1782 & 0.2737 & $0.002 * \star$ \\
\hline Light & -0.4595 & 0.8882 & 0.524 & $<0.001 * * *$ \\
\hline
\end{tabular}

In recent forests, the effect of interaction between the distance from the river and the distance from the ancient forest, was not significant, either for richness of forest species or for overall species richness. Similar results were also found for the richness of autochorous, anemochorous, endozoochorous, epizoochorous and myrmecochorous species in recent forests (see Supplement Table 2).

\section{Discussion}

Our results support the view that colonisation patterns of plant species strongly reflect the riverine gradient. Our results show a higher saturation of plant species in recent forests and this finding is consistent with our predictions that recent forests in river valleys are exposed to higher migration. Conversely, the proportion of plant species in the recent forests decreased with increasing distance from the river valley. The results indicate that migration processes are more important in river valleys than away from them, confirming the view that river valleys are important migration corridors compared to the surrounding flat landscapes.

The lower richness of forest species found at some distances from the river valley is consistent with other studies which found evidence for low saturation in recent forests (Peterken and Game 1984; Dzwonko and Gawronsky 1992; Hermy et al. 1999; Wulf 2003; Sciama et al. 2009; Matuszkiewicz et al. 2013). In most of these studies, the dearth of forest species is interpreted as being a consequence of limited dispersal or of unsuitable recruitment conditions (Ehrlén and Eriksson 2000; Ehrlén et al. 2006).

According to the dispersal limitation hypothesis (1), forest species that are unable to rapidly colonise recently developed forests, are primarily associated with ancient forests (Hermy et al. 1999; StefańskaKrzaczek et al. 2016). The reason for this is that these species are adapted to small scale disturbance regimes in temperate forests, where species usually spread only over quite short distances as they colonise canopy gaps (Hermy et al. 1999; Bellemare et al. 2002). For example, many forest species are dispersed locally by ants, some species of which are very sensitive to habitat fragmentation and rarely travel through treeless areas (Hermy et al. 1999, Mitchell et al. 2002, Douda 2010). The observed patterns 
in richness of myrmecochorous species support this view as the values between ancient and recent forest are more similar in the river valley (Fig. 3e).

Meanwhile, the recruitment limitation hypothesis (2) states that in a recent forest site, the altered soil characteristics resulting from the former agricultural use are retained. These include, increased $\mathrm{pH}$, base saturation and a greater availability of phosphate and nitrogen (Dzwonko and Loster 1994; Richter et al. 1994; Koerner et al. 1997; Honnay et al. 1999). These altered soil conditions restrict the recruitment and population growth of forest species, even though they are able to colonise the site (Hurtt and Pacala 1995).

The second hypothesis does not seem able to account satisfactorily for the patterns of species saturation we observed. We would also expect a poor saturation of recent forests in the river valley if the recruitment limitation due to altered soil conditions. Instead, the contrast between the levels of forest species in the river valley and in the surrounding landscape suggests that dispersal limitation occurs outside of the river valley, with easier dispersal within the river valley. Contrary to the recruitment limitation hypothesis, we did not find differences in the EIVs, which might indicate the different levels of nutrients, light availability or moisture found between recent and ancient forests.

The patterns of overall species richness also supports easier dispersal within the river valley, as higher numbers of species are associated with recent forests in the river valley. However, outside the river valley, the effects of dispersal limitation are not so clear, as the values between ancient and recent forests are highly comparable. It should be recognised that in this study we include all plant species recorded in the forests, not just the species belonging to the forest-species category. In other words, plant species could still persist in recent forests that occurred in a previously open habitat.

The reverse species richness patterns were observed in the river valley where more plant species occurred in recent forests than in ancient forests. The over-occupancy of recent forests could be explained by a combination of a fast colonisation rate and a slow extinction rate in the river valley. It is well known that competition among species can be relatively weak early in forest succession during the initial establishment of plant populations, whereas the importance of interspecific competition for light and nutrients grows as a population becomes more established (Slatkin 1974; Goldberg and Barton 1992). At the start of a succession (i.e., in recent forests), a higher colonisation rate leads to an accumulation of species, whereas in later stages of succession (i.e., in ancient forests) the increasing role of competition limits the successful recruitment of new colonisers and leads to elimination of some species from the community. The number of species in ancient forests is determined by the long-term balance between species carrying capacity, the colonisation rate and the extinction rate (Connell and Slatyer 1977; Tilman 1990; Ehrlén and Groenendael 1998, Kneitel and Chase 2004). We expect low levels of interspecific competition at the start of a succession leading to a rapid recruitment of plant species in recent forests that outnumber those in ancient forests. That this occurred only in the river valley, indicating that colonisation rate is higher there than it is in the surrounding landscape. Moreover, a higher colonisation rate in the river valley should also be reflected in a higher proportion of plant species with various 
dispersal modes in recent forests. This was confirmed at least in the cases of the autochorous, endozoochorous and myrmecochorous species (Table 1; Fig. 3).

In the future, we would expect a gradual decrease in plant species-richness in the recent forests as it declines to the level observed in ancient forests. However, population decline in perennial species, and especially in forest species, is a very slow process, so the gradual extinction of many forest species is much delayed (Tilman et al. 1994; Vellend et al. 2006).

River valleys may favour species migration for a number of reasons. Among these are the increased finescale habitat heterogeneity in such a variable topography, both the mesoclimate and the geological conditions. The topography of a river valley is characterised by steep slopes with exposed rocky outcrops, flat alluvial areas and variable landform shapes (Jeník and Slavíková 1964). Also, frequent temperature inversions result from the valley shape, and these increase the contrast between a cold and wet valley bottom and a dry, more continental upper valley edge (Chytrý and Tichý 1998). Similarly, north facing and south facing slopes represent suitable habitats for shade-demanding and light-demanding species so enabling the close coexistence of these species within a river valley (Blažková 1964; Chytrý and Tichý 1998; Zelený and Chytrý 2007). All these abiotic variables create a set of suitable environmental conditions, which may host a large spectrum of species with quite different habitat requirements. This fines-scale heterogeneity may enhance the connectivity of a river valley for multiple species, rather than presenting a barrier to their migration.

Contrary to the expectation based on numerous studies (Blažková 1964; Ložek 1974; Chytrý and Tichý 1998; Renöfält et al. 2005; Zelený and Chytrý 2007; Nobis et al. 2016), we found the distance from the river was positively associated with plant species-richness. The likely explanation for this is that environmental conditions are more favourable here, so more plant species can establish successfully. This explanation is supported by the increasing EIVs for nutrients with distance from the river as shown in Fig. 4. Moreover, higher resource availability in the surrounding landscape is also suggested by the DCA ordination in which the nutrient and water availabilities are also highly correlated with distance from the river (Fig. 5).

Higher productivity in the surrounding landscape appears to be associated mainly with geological conditions. The geological base for our whole study area comprised two main geological formations: volcanic rocks (predominant in the river valley) and clay sediments (predominant in the surrounding landscape). These have fundamentally different in water holding properties (see Supplement Fig. 1). Clay sediments retain water in the upper levels of the soil horizon and thus create the appropriate moisture conditions for plant species during the larger part of the growing season. Conversely, highly waterpermeable volcanic rocks can lose water earlier in the growing season, and this can lead to severe water stress and to a decline in species richness (Cannon 1971; Lite et al. 2005). In general, forest species are adapted to deep, moist soils rather than to the more extreme habitats of exposed rocky outcrops, where dry-grassland species increase their proportion (Chytrý and Tichý 2003; Douda et al. 2017). 
Many studies mention river valleys as important migration corridors for plant species (Jeník and Slavíková 1964; Tockner and Ward 1999; Ward et al. 2001; Saarela et al. 2017). However, none of these compare the colonisation rates in river valleys with those in the surrounding landscape. This also includes studies of invasive plant species for which dispersal along rivers is fundamental to their rapid spread outside of their native range (Hood and Naiman 2000; Richardson et al. 2007; Osawa et al. 2013; Aronson et al. 2017). In this study, we used an original approach to compare community saturation by plant species along a riverine gradient. Ancient forests served as a control where species richness is determined by the balance between species carrying capacity, colonisation rate and extinction rate. Under these conditions, the proportion of plant species in recent forests compared with that in ancient forests becomes a measure of colonisation rate. As predicted, the recent forests in the river valley were saturated with plant species as they had been exposed to a high colonisation rate. This result confirms the strong importance of river valleys as natural corridors for species migration. River valleys may also serve as refuges for endangered plant species, with rapid dispersal among river sites helping prevent their extinction. Unfortunately, recent large constructions for irrigation, for hydropower and reservoirs for urban water supply have cause major fragmentation of these river-valley habitats (Nilsson et al. 2005). We hope that our results will serve to underpin conservation efforts and for the prioritisation of river valleys in conservation strategies.

\section{Declarations}

\section{Funding}

This study was supported by the project - The understanding of long-term sustainability of ecosystem services of European floodplain forests (LTC18045) of the Ministry of Education, Youth and Sports of the Czech Republic, and Vegetation changes and biodiversity conservation of floodplain forests situated along the regulated rivers (2020B0035) of the Faculty of Environmental Sciences, Czech University of Life Sciences Prague.

\section{Conflicts of interest/Competing interests}

Not applicable

\section{Ethics approval}

Not applicable

\section{Consent to participate}

Not applicable

Consent for publication

Availability of data and material 
Data available: $\mathrm{XXX}$

\section{Code availability}

Not applicable

\section{Authors' contributions}

J.D. and A.H.: conceived of the research; A.H. collected the data; J.D. and A.H. carried out the statistical analyses; A.H., with contributions from J.D., wrote the paper.

\section{ACKNOWLEDGEMENTS}

We thank Jana Doudová for carefully reading the manuscript and making comments. Sandy Lang is thanked for helping with the language of the manuscript. This study was supported by the project - The understanding of long-term sustainability of ecosystem services of European floodplain forests (LTC18045) of the Ministry of Education, Youth and Sports of the Czech Republic and Vegetation changes and biodiversity conservation of floodplain forests situated along the regulated rivers (2020B0035) of the Faculty of Environmental Sciences, Czech University of Life Sciences Prague.

\section{References}

Aronson MFJ, Patel MV, O’Neill KM, Ehrenfeld JG (2017) Urban riparian systems function as corridors for both native and invasive plant species. Biological Invasions 19: 3645-3657.

https://doi.org/10.1007/s10530-017-1583-1

Bellemare J, Motzkin G, Foster DR (2002) Legacies of the agricultural past in the forested present: an assessment of historical land-use effects on rich mesic forests. Journal of Biogeography 29: 1401-1420. https://doi.org/10.1046/j.1365-2699.2002.00762.x

Bína J, Demek J (2012) Z nížin do hor. Geomorfologické jednotky České republiky. / From the lowlands to the mountains. Geomorphological units of the Czech Republic (Czech). Academia, Prague

Blažková D (1964) Rozčlenění vegetace na údolních svazích v oblasti Orlické nádrže. Vegetační problémy při budování vodních děl. / Distribution of vegetation at the valley slopes in the Orlická reservoir area.

Vegetation problems in building water works (Czech). NČSAV, Prague, pp 21-37

Braun-Blanquet J (1964) Pflanzensoziologie. Grundzüge der Vegetationskunde. 3rd edn. Springer, Wien, New York

Cannon HL (1971) The use of plant indicators in ground water surveys, geologic mapping, and mineral prospecting. Taxon 20: 227-256. https://doi.org/10.2307/1218878 
Connell JH, Slatyer RO (1977) Mechanisms of succession in natural communities and their role in community stability and organization. The American Naturalist 111: 1119-1144.

https://doi.org/10.1086/283241

Czochański J, Wiśniewski P (2018) River valleys as ecological corridors - structure, function and importance in the conservation of natural resources. Ecological Questions 29:77-87.

http://dx.doi.org/10.12775/EQ.2018.006

Douda J (2010) The role of landscape configuration in plant composition of floodplain forests across different physiographic areas. Journal of Vegetation Science 21: 1110-1124.

https://doi.org/10.1111/j.1654-1103.2010.01213.x

Douda J, Boublík K, Doudová J, Kyncl M (2017) Traditional forest management practices stop forest succession and bring back rare plant species. Journal of Applied Ecology 54: 761-771.

https://doi.org/10.1111/1365-2664.12801

Dzwonko Z (1993) Relations between the floristic composition of isolated young woods and their proximity to ancient woodland. Journal of Vegetation Science 4: 693-698.

https://doi.org/10.2307/3236135

Dzwonko Z, Gawronsky S (1994) The role of woodland fragments, soil types, and dominant species in secondary succession on the western Carpathian foothills. Vegetatio 111: 149-160.

https://doi.org/10.1007/BF00040334

Dzwonko Z, Loster S (1992) Species richness and seed dispersal to secondary woods in southern Poland. Journal of Biogeography 19: 195-204. https://doi.org/10.2307/2845505

Ehrlén J, Eriksson 0 (2000) Dispersal limitation and patch occupancy in forest herbs. Ecology 81: 16671674. https://doi.org/10.1890/0012-658(2000)081[1667:DLAPOI]2.0.C0;2

Ehrlén J, Münzbergova Z, Diekmann M, Eriksson O (2006) Long-term assessment of seed limitation in plants: results from an 11-year experiment. Journal of Ecology 94: 1224-1232.

https://doi.org/10.1111/j.1365-2745.2006.01169.x

Ehrlén J, van Groenendael J (1998) The trade-off between dispersability and longevity - an important aspect of plant species diversity. Applied Vegetation Science 1: 29-36. https://doi.org/10.2307/1479083

Ellenberg H, Weber HE, Düll R, Wirth W, Werner W, PauliBen D (1992) Zeigerwerte von Pflanzen in Mitteleuropa. Scripta Geobotanica 18: 1-258.

Gallé L, Margóczi K, Kovács É, Györffy G, Körmöczi L, Németh L (1995) River valleys: Are they ecological corridors? Tiscia 29: 53-58. 
Goldberg DE, Barton AM (1992) Patterns and consequences of interspecific competition in natural communities: a review of field experiments with plants. American Naturalist 139: 771-801. https://doi.org/10.1086/285357

Hermy M, Honnay O, Firbank L, Grashof-Bokdam C, Lawesson JE (1999) An ecological comparison between ancient and other forest plant species of Europe, and the implications for forest conservation. Biological Conservation 91: 9-22. https://doi.org/10.1016/S0006-3207(99)00045-2

Hood WG, Naiman RJ (2000) Vulnerability of riparian zones to invasion by exotic vascular plants. Plant Ecology 148: 105-114. https://doi.org/10.1023/A:1009800327334

Honnay O, Hermy M, Coppin P (1999) Impact of habitat quality on forest plant species colonization. Forest Ecology and Management 115: 157-170. https://doi.org/10.1016/S0378-1127(98)00396-X

Hurtt GC, Pacala SW (1995) The consequences of recruitment limitation: reconciling chance, history and competitive differences between plants. Journal of Theoretical Biology 176: 1-12. https://doi.org/10.1006/jtbi.1995.0170.

Chytrý M (2013) 4. Lesní a křovinná vegetace. In: Chytrý M (ed) Vegetace České republiky. / 4. Forest and Scrub Vegetation. In: Chytrý M (ed) Vegetation of the Czech Republic. Academia, Prague

Chytrý M, Tichý L (1998) Phenological mapping in a topographically complex landscape by combining field survey with an irradiation model. Applied Vegetation Science 1: 225-232. https://doi.org/10.2307/1478952

Chytrý M, Tichý L (2003) Diagnostic, constant and dominant species of vegetation classes and alliances of the Czech Republic: a statistical revision. Masaryk University, Brno

Jeník J, Slavíková J (1964) Střední Vltava a její přehrady z hlediska geobotanického. In: Jeník J (ed) Vegetační problémy při budování vodních děl / The middle course of the Vltava River and its dams from a geobotanical point of view. In: Jeník J (ed) Vegetation problems in building water works (Czech). NČSAV, Prague, pp 67-100

Kachlík V (2003) Geologický vývoj území České republiky. / Geological development of the Czech Republic territory (Czech). SÚRAO, Prague

Kaplan Z, Danihelka J, Chrtek J jun, Kirschner J, Kubát K, Štech M, Štěpánek J (2019) Klíč ke květeně České republiky/ Key to the flora of the Czech Republic. 2nd edn. Academia, Praha, pp 1168

Kleyer M, Bekker RM, Knevel IC, Bakker JP, Thompson K, Sonnenschein M et al (2008) The LEDA Traitbase: A database of life-history traits of Northwest European flora. Journal of Ecology 96: 12661274. https://doi.org/10.1111/j.1365-2745.2008.01430.x 
Kneitel JM, Chase JM (2004) Trade-offs in community ecology: linking spatial scales and species coexistence. Ecology Letters 7: 69-80. https://doi.org/10.1046/j.1461-0248.2003.00551.x

Koerner W, Dupouey JL, Dambrine E, Benoit M (1997) Influence of past land use on the vegetation and soils of present day forest in the Vosges mountains, France. Journal of Ecology 85: 351-358. https://doi.org/10.2307/2960507

Lite SJ, Bagstad KJ, Stromberg JC (2005) Riparian plant species richness along lateral and longitudinal gradients of water stress and flood disturbance, San Pedro River, Arizona, USA. Journal of Arid Environments 63: 785-813. https://doi.org/10.1016/j.jaridenv.2005.03.026.

Ložek V (1974) Říční fenomén Vltavy a Sázavy. / River phenomenon of the Vltava and Sázava Rivers (Czech). Sborník vlastivědných prací z Podblanicka 15: 7-15

Naiman RJ, Decamps H, Pollock M (1993) The role of riparian corridors in maintaining regional biodiversity. Ecological Applications 3: 209-212. https://doi.org/10.2307/1941822

Nilsson C, Reidy CA, Dynesius M, Revenga C (2005) Fragmentation and flow regulation of the world's large river systems. Science 308: 405-408. https://doi.org/10.1126/science.1107887

Nobis A, Żmihorski M, Kotowska D (2016) Linking the diversity of native flora to land cover heterogeneity and plant invasions in a river valley. Biological Conservation 203: 17-24.

https://doi.org/10.1016/j.biocon.2016.08.032

Nobis A, Rola K, Węgrzyn M (2017) Detailed study of a river corridor plant distribution pattern provides implications for river valley conservation. Ecological Indicators 83: 314-322.

https://doi.org/10.1016/j.ecolind.2017.07.040

Mather AS, Fairbairn J, Needle CL (1999) The course and drivers of the forest transition: the case of France. Journal of Rural Studies 15: 65-90. https://doi.org/10.1016/S0743-0167(98)00023-0

Matuszkiewicz JM, Kowalska A, Kozłowska A, Roo-Zielińska E, Solon J (2013) Differences in plantspecies composition, richness and community structure in ancient and post-agricultural pine forests in central Poland. Forest Ecology and Management 310: 567-576.

https://doi.org/10.1016/j.foreco.2013.08.060

Mitchell CE, Turner MG, Pearson SM (2002) Effects of historical land use and forest patch size on myrmecochores and ant communities. Ecological Applications 12: 1364-1377.

https://doi.org/10.1890/1051-0761(2002)012[1364:EOHLUA]2.0.CO;2

Oksanen FJ, Blanchet FG, Kindt R, Legendre P, O'hara RB, Simpson GL et al (2017) Vegan: Community Ecology Package. $\mathrm{R}$ package Version 2.4-3. https://CRAN.R-project.org/package=vegan 
Orczewska A (2010) Colonization capacity of herb woodland species in fertile, recent alder woods adjacent to ancient forest sites, Poland. Polish Journal of Ecology 58: 297-310.

Orczewska A, Fernes M (2011) Migration of herb layer species into the poorest post-agricultural pine woods adjacent to ancient pine forests, Poland. Polish Journal of Ecology 59: 75-85.

Osawa T, Mitsuhashi H, Niwa H (2013) Many alien invasive plants disperse against the direction of stream flow in riparian areas. Ecological Complexity 15: 26-32.

https://doi.org/10.1016/j.ecocom.2013.01.009.

Peterken GF, Game M (1984) Historical factors affecting the number and distribution of vascular plant species in the woodlands of central Lincolnshire. Journal of Ecology 72: 155-182. https://doi.org/10.2307/2260011

Podani J (1984) Spatial processes in the analysis of vegetation: Theory and review. Acta Botanica Hungarica 30: 75-118.

Pongratz J, Reick C, Raddatz T, Claussen M (2008) A reconstruction of global agricultural areas and land cover for the last millennium. Global Biogeochemical Cycles 22: 1-16.

https://doi.org/10.1029/2007GB003153

R Core Team (2019) R: A language and environment for statistical computing. R Foundation for Statistical Computing, Vienna, Austria. URL https://www.R-project.org/.

Renöfält BM, Nilsson C, Jansson R (2005) Spatial and temporal patterns of species richness in a riparian landscape. Journal of Biogeography 32: 2025-2037. https://doi.org/10.1111/j.1365-2699.2005.01328.x

Richardson DM, Holmes PM, Esler KJ, Galatowitsch SM, Stromberg JC, Kirkman SP et al (2007) Riparian vegetation: degradation, alien plant invasions, and restoration prospects. Diversity and Distributions 13: 126-139. https://doi.org/10.1111/j.1366-9516.2006.00314.x

Richter DD, Markewitz D, Wells CG, Allen HL, April R, Heine PR et al (1994) Soil chemical change during three decades in an old-field loblolly pine (Pinus taeda L.) ecosystem. Ecology 75: 1463-1473. https://doi.org/10.2307/1937469

Saarela JM, Sokoloff PC, Bull RD (2017) Vascular plant biodiversity of the lower Coppermine River valley and vicinity (Nunavut, Canada): an annotated checklist of an Arctic flora. PeerJ 5: e2835. https://doi.org/10.7717/peerj.2835

Sciama D, Augusto L, Dupouey JL, Gonzalez M, Moares Domínguez C (2009) Floristic and ecological differences between recent and ancient forests growing on non-acidic soils. Forest Ecology and Management 258: 600-608. https://doi.org/10.1016/j.foreco.2009.04.027 
Slatkin M (1974) Competition and regional coexistence. Ecology 55: 128-134.

https://doi.org/10.2307/1934625

Stefańska-Krzaczek E, Kącki Z, Szypuła B (2016) Coexistence of ancient forest species as an indicator of high species richness. Forest Ecology and Management 365: 12-21.

https://doi.org/10.1016/j.foreco.2016.01.012

Tilman D (1990) Constraints and tradeoffs: toward a predictive theory of competition and succession. Oikos 58: 3-15. https://doi.org/10.2307/3565355

Tilman D, May R, Lehman C, Nowak MH (1994) Habitat destruction and the extinction debt. Nature 371: 65-66. https://doi.org/10.1038/371065a0

Tockner K, Ward JV (1999) Biodiversity along riparian corridors. Large Rivers 11: 293-310. https://doi.org/10.2307/3545432

Vellend M (2016) The theory of ecological communities (MPB-57). Princeton University Press

Vellend M, Verheyen K, Jacquemyn H, Kolb A, van Calster H, Peterken G et al (2006) Extinction debt of forest plants persists for more than a century following habitat fragmentation. Ecology 87: 542-548. https://doi.org/10.1890/05-1182

Ward JV, Tockner K, Arscott DB, Claret C (2002) Riverine landscape diversity. Freshwater Biology 47: 517539. https://doi.org/10.1046/j.1365-2427.2002.00893.x

Ward JV, Tockner K, Uehlinger U, Malard F (2001) Understanding natural patterns and processes in river corridors as the basis for effective river restoration. Regulated Rivers 17: 311-323.

https://doi.org/10.1002/rrr.646

Webb NR (1998) The traditional management of European heathlands. Journal of Applied

Ecology 35: 987-990. https://doi.org/10.1111/j.1365-2664.1998.tb00020.x

Wulf M (2003) Preference of plant species for woodlands with differing habitat continuity. Flora 198: 444-460. https://doi.org/10.1078/0367-2530-00118

Wulf M, Heinken T (2008) Colonization of recent coniferous versus deciduous forest stands by vascular plants at the local scale. Applied Vegetation Science 11: 307-316. https://doi.org/10.3170/2008-7-18432

Yao J, Holt RD, Rich PM, Marshall WS (1999) Woody plant colonization in an experimentally fragmented landscape. Ecography 22: 715-728. https://doi.org/10.1111/j.1600-0587.1999.tb00521.x

Zelený D, Chytrý M (2007) Environmental control of the vegetation pattern in deep river valleys of the Bohemian Massif. Preslia 79: 205-222. 


\section{Figures}

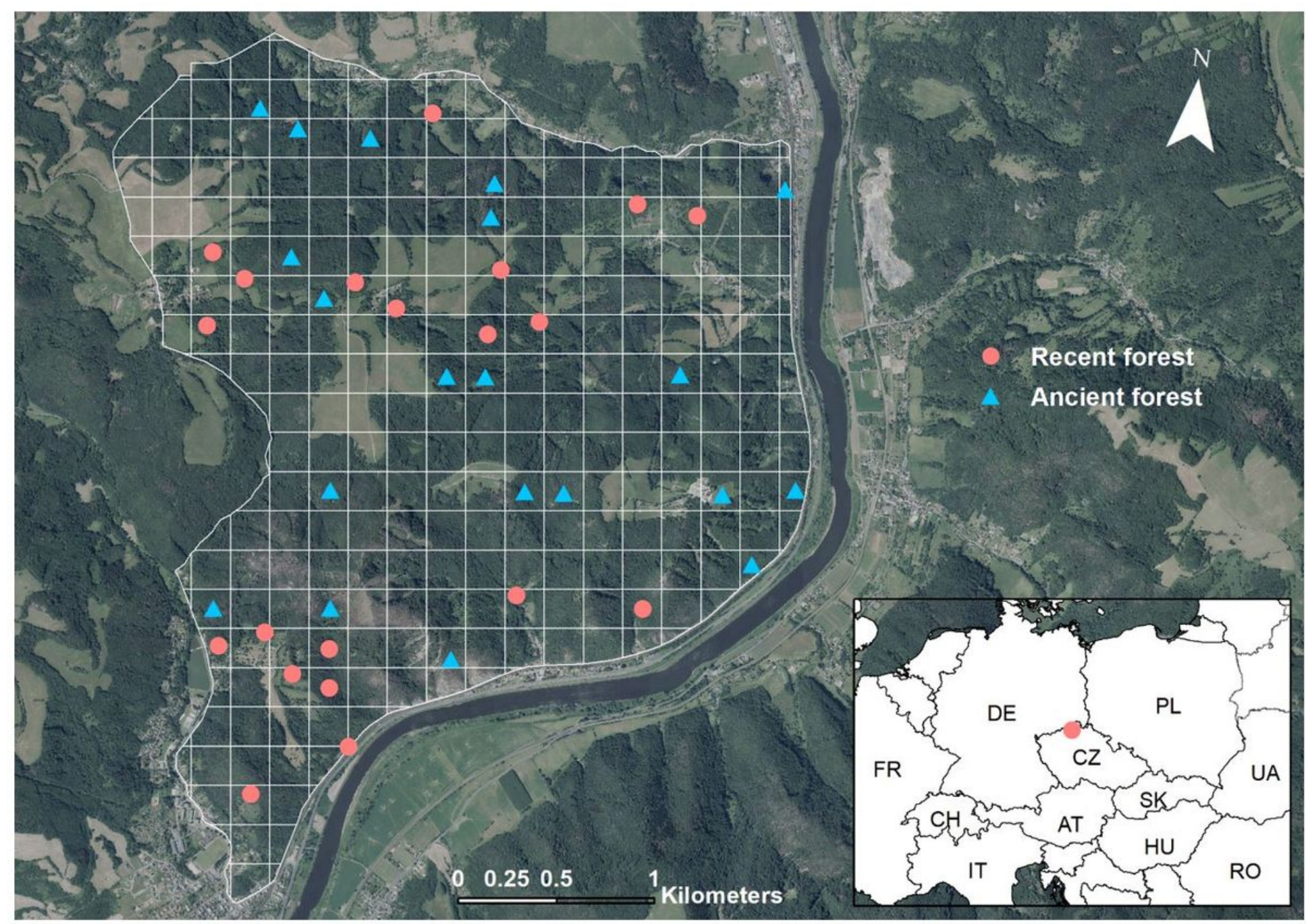

\section{Figure 1}

Study area with 40 vegetation plots distinguished as being either recent or ancient forest. Note: The designations employed and the presentation of the material on this map do not imply the expression of any opinion whatsoever on the part of Research Square concerning the legal status of any country, territory, city or area or of its authorities, or concerning the delimitation of its frontiers or boundaries. This map has been provided by the authors. 


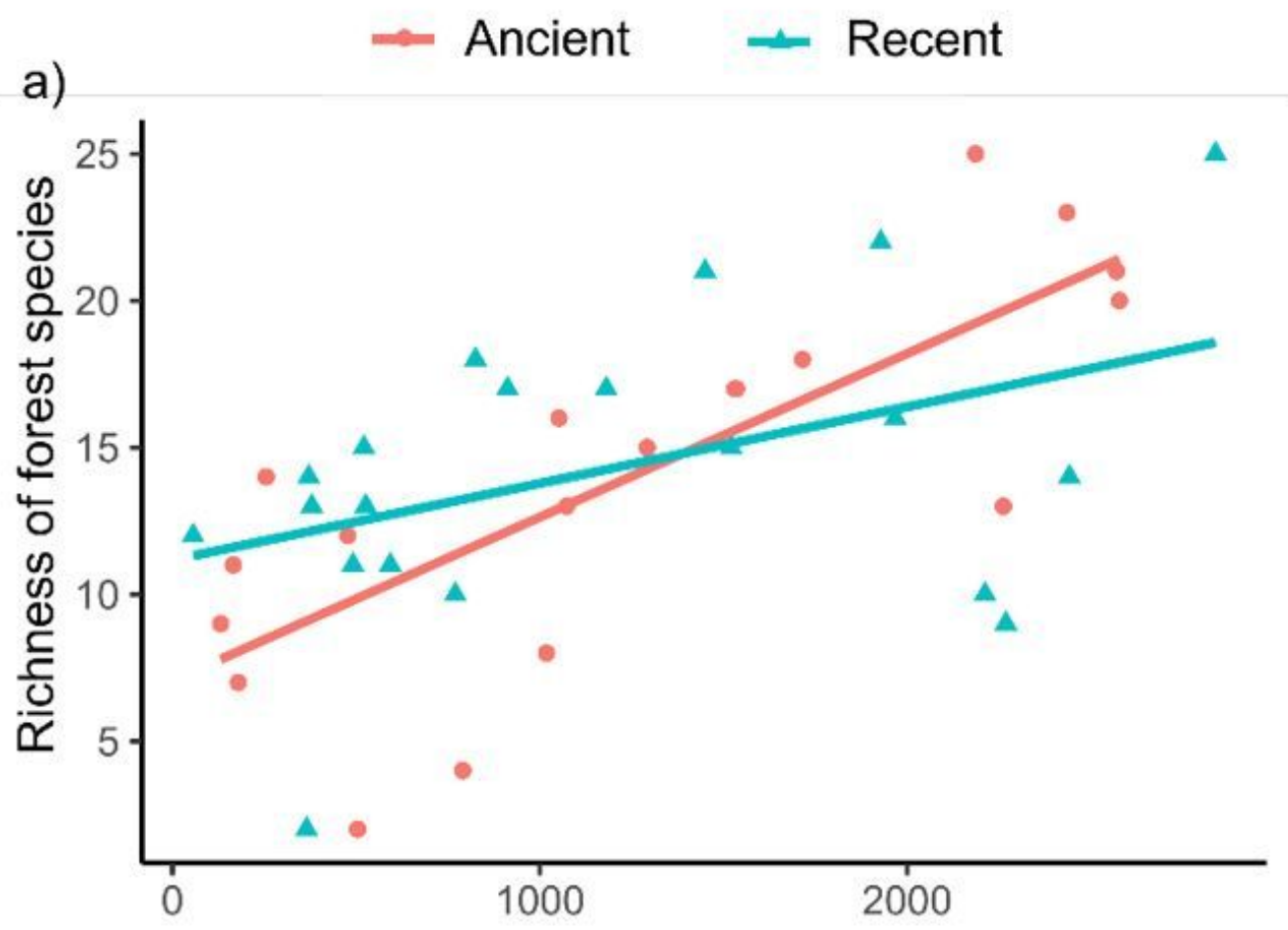

b)

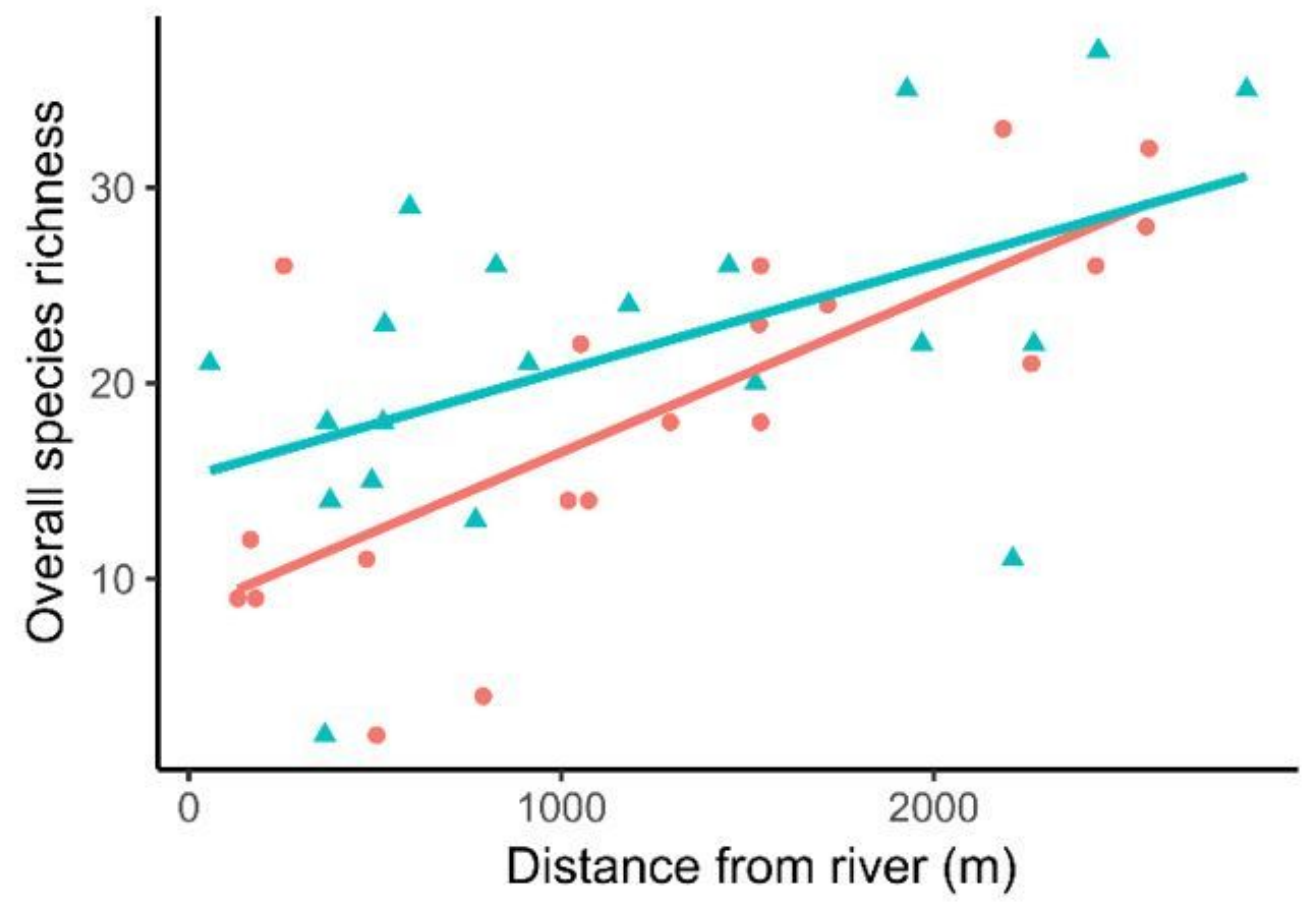

Figure 2

The effect of distance from the river on a) richness of forest species, b) overall species richness distinguished as being either recent or ancient forest. 
a) $\leftarrow$ Ancient $\leftarrow$ Recent

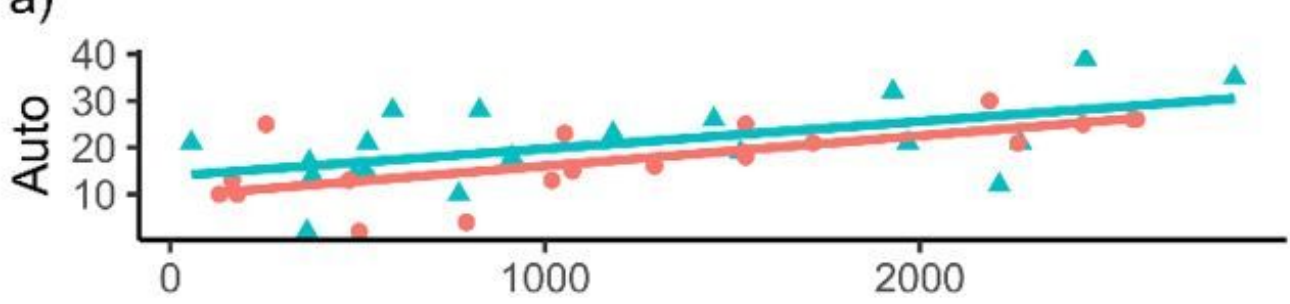

b)

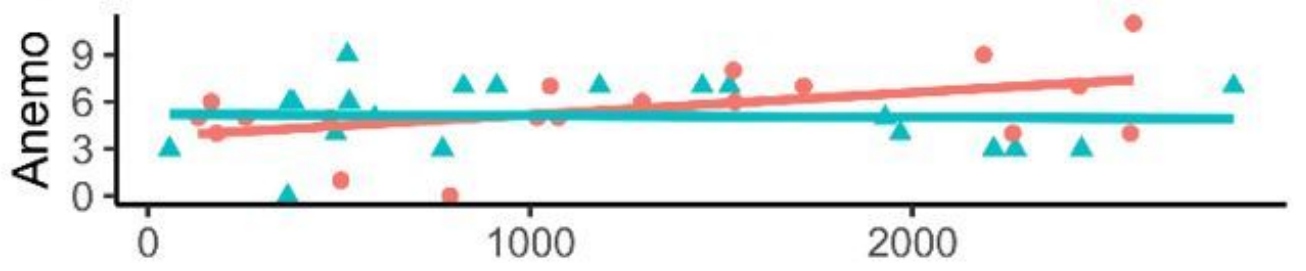

c)

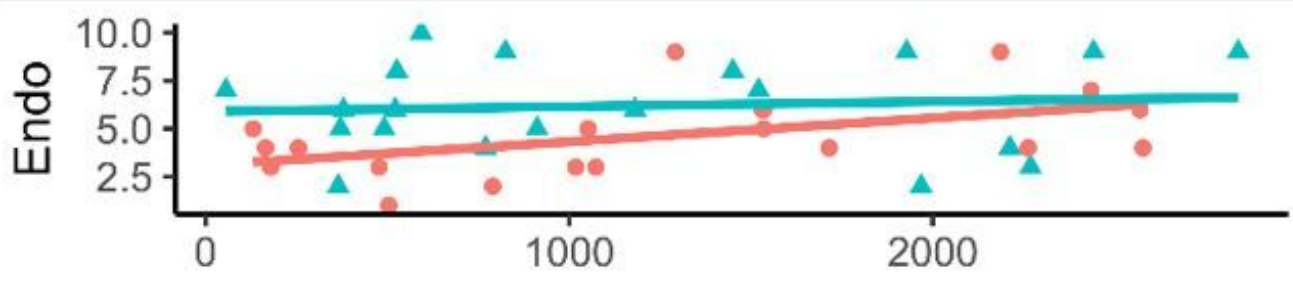

d)

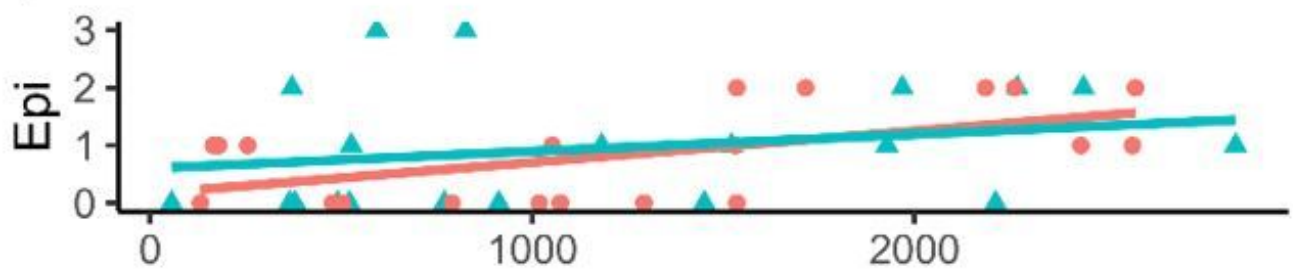

e)

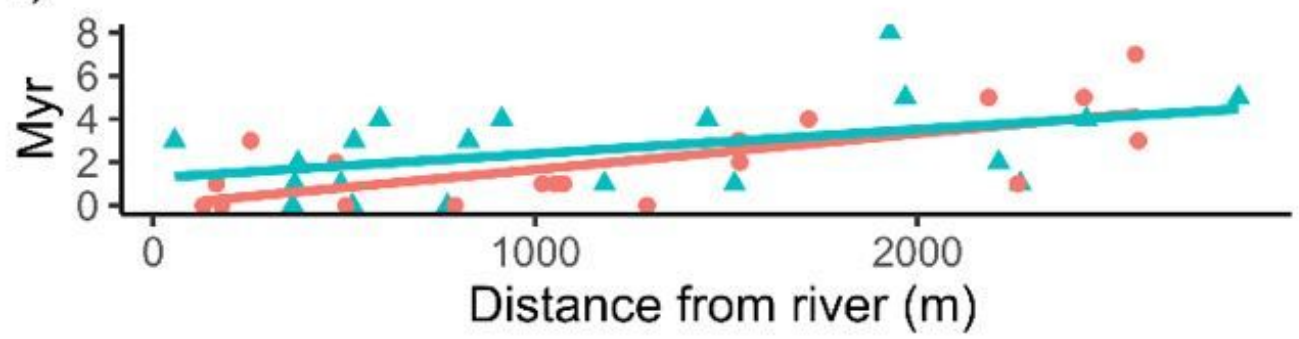

\section{Figure 3}

The effect of distance from the river on richness of a) autochorous, b) anemochorous, c) endozoochorous, d) epizoochorous and e) myrmecochorous species, distinguished as being either recent or ancient forest. 


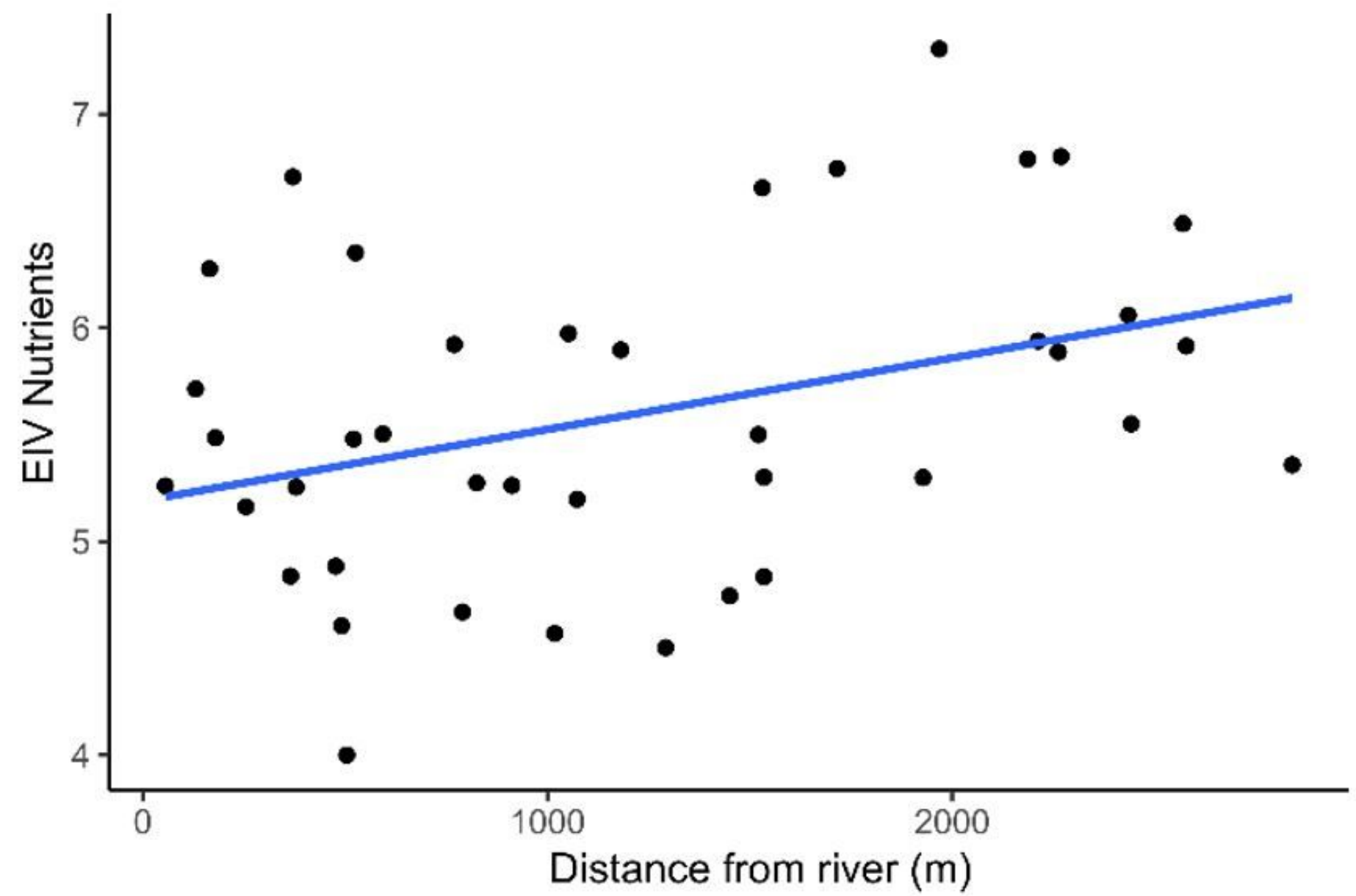

Figure 4

The effect of distance from the river on Ellenberg indicator values for nutrients. 


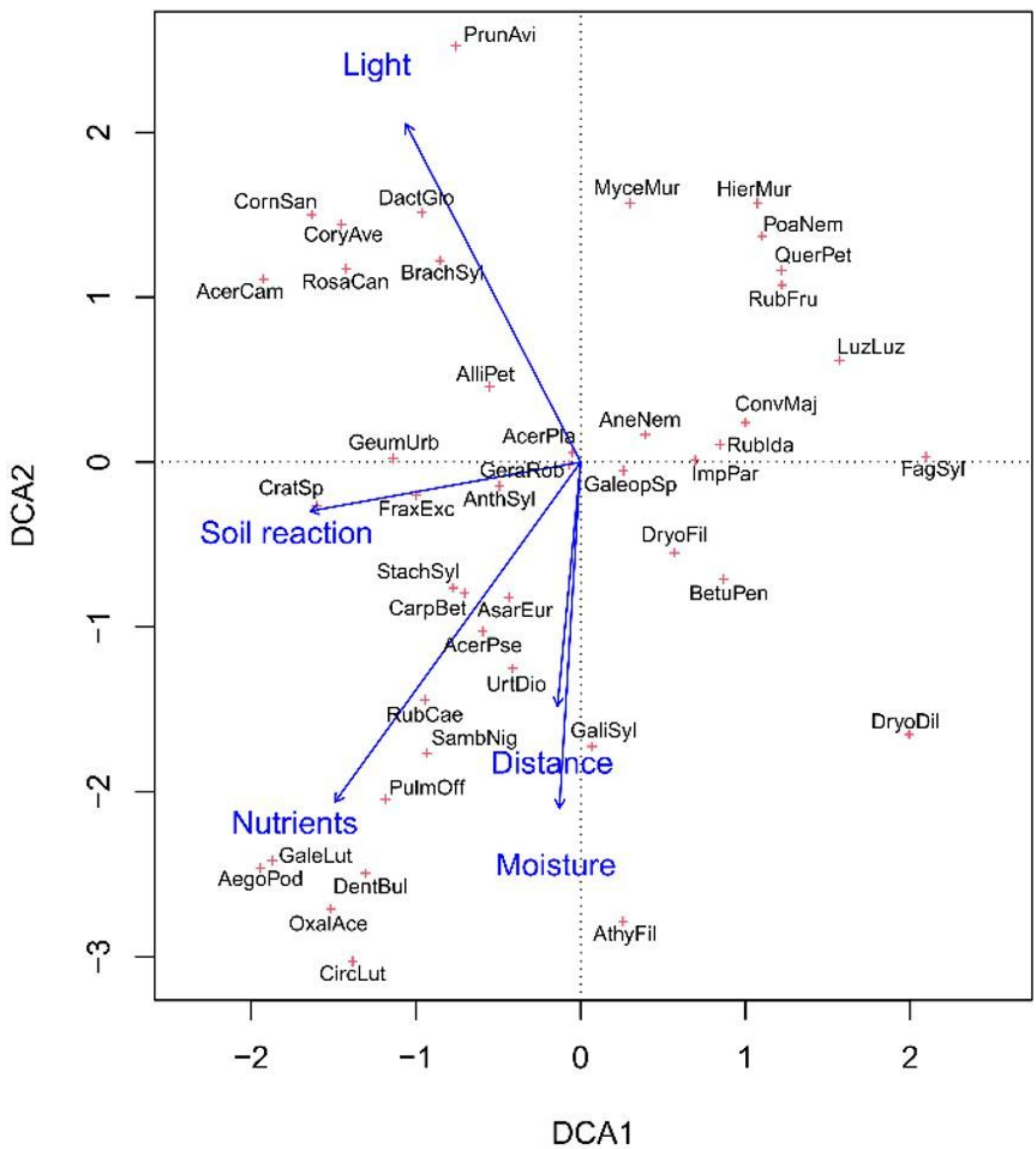

\section{Figure 5}

The variation in species composition with significant environmental variables as detected by DCA and the envfit function from the R package Vegan. The first and second ordination axes explained 16.2 and $10.4 \%$ of the total variation, respectively. Abbreviations: PrunAvi, Prunus avium; CornSan, Cornus sanguinea; DactGlo, Dactylis glomerata; CoryAve, Corylus avellana; AcerCam, Acer campestre; RosaCan, Rosa canina; BrachSyl, Brachypodium sylvaticum; AlliPet, Alliaria petiolata; GeumUrb, Geum urbanum; 
AcerPla, Acer platanoides; MyceMur, Mycelis muralis; HierMur, Hieracium murorum; PoaNem, Poa nemoralis; QuerPet, Quercus petraea; RubFru, Rubus fruticosus agg.; LuzLuz, Luzula luzuloides; ConvMaj, Convallaria majalis; AneNem, Anemone nemorosa; Rublda, Rubus idaeus; ImpPar, Impatiens parviflora; FagSyl, Fagus sylvatica; GaleopSp, Galeopsis sp.; DryoFil, Dryopteris filix-mas; BetuPen, Betula pendula; DryoDil, Dryopteris dilatata; GaliSyl, Galium sylvaticum; AthyFil, Athyrium filix-femina; GeraRob, Geranium robertianum; CratSp, Crataegus sp.; AnthSyl, Anthriscus sylvestris; FraxExc, Fraxinus excelsior; StachSyl, Stachys sylvatica; CarpBet, Carpinus betulus; AsarEur, Asarum europaeum; AcerPse, Acer pseudoplatanus; UrtDio, Urtica dioica; RubCae, Rubus caesius; SambNig, Sambucus nigra; PulmOff, Pulmonaria officinalis; GaleLut, Galeobdolon luteum; AegoPod, Aegopodium podagraria; DentBul, Dentaria bulbifera; OxalAce, Oxalis acetosella; CircLut, Circaea lutetiana. 